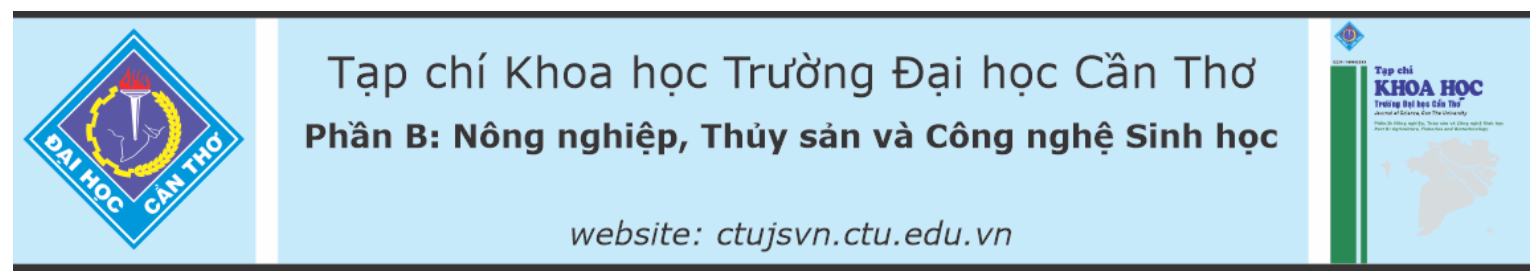

DOI:10.22144/ctu.jvn.2021.191

\title{
ĐA DANG THÀNH PHÀ̀ LOÀI CÁ Ở VÙNG LÕI VƯờN QUỐC GIA U MINH THƯợNG, TỈNH KIÊN GIANG
}

\author{
Trương Thị Ngọc Thu ${ }^{1,2}$, Nguyễn Trung Tín ${ }^{3}$, Trần Văn Thắng ${ }^{4}$ và Trần Văn Việt ${ }^{3^{*}}$ \\ ${ }^{1} H o$ c viên cao học Nuôi trồng thủy sản Khóa 26, Khoa Thủy sản, Truờng Đại học Cần Tho' \\ ${ }^{2}$ Sở Nông nghiệp và Phát triển Nông thôn tỉnh Sóc Trăng \\ ${ }^{3}$ Khoa Thủy sản, Truoòng Đại học Cần Tho \\ ${ }^{4}$ Vuoòn Quốc gia U Minh Thuợng, tỉnh Kiên Giang \\ *Người chịu trách nhiệm về bài viết: Trần Văn Việt (email: tvviet@ctu.edu.vn)
}

\section{Thông tin chung:}

Ngày nhận bài: 14/07/2021

Ngày nhận bài sưa: 22/10/2021

Ngày duyệt đăng: 25/12/2021

Title:

Fish diversity in the core zone of U Minh Thuong National Park, Kien Giang province, Viet Nam

\section{Tù khóa:}

Chi số đa dạng sinh học, thành phần loài cá, vùng lõi, vuoòn quốc gia U Minh Thuơng

\section{Keywords:}

Biodiversity index, core region, fish composition, $U$ Minh Thuong National Park

\begin{abstract}
A study on diversity of fish composition in the core zone of U Minh Thuong National Park was carried out from 2020 to 2021 in order to (i) identify the status of water management and fish resource, (ii) determine species composition of fish, and (iii) identify diversity levels of fish. The study was conducted at 15 sites of four habitats in the core zone and one buffer zone. At each habitat, three samppling sites were sellected with four sampling periods (May, July, October 2020 and January 2021). Different types of fishing gears, fixed and portable, were used for sampling. All fish specimens were identified to species name, weighted ( $\mathrm{g} / \mathrm{ind}$.) and measured the total length $(\mathrm{cm})$. Besides, Margalef index (d), Simpson index (1-D) and Shannon - Wiener index $\left(H^{\prime}\right)$ were applied to evaluate biodiversity levels. The results showed that lack of freshwater in the dry season affected the significantly abundance of fish in the core zone. There were 32 fish species identified belonging to 6 orders and 17 families. In the core zone, the diversity of fish compostion was higher and stabler than that in the buffer zone in both habitats and various time in a year, influenced by different water levels.
\end{abstract}

\section{TÓM TẮT}

Nghiên cứu về sư đa dạng thành phần loài cá ở vìng lõi Vườn Quốc gia $U$ Minh Thuợng tỉnh Kiên Giang được thực hiện tù̀ năm 2020 đến năm 2021 nhằm xác định (i) hiện trạng quản lý nước và nguồn lợi cá, (ii) thành phần loài cá, và (iii) chỉ số đa dạng sinh học. Trong đó, 15 điểm thu mẫu trong 4 sinh cảnh khác nhau ở vùng lõi và một vùng đệm được tiến hành với 4 đọt thu mẫu vào các tháng 5, tháng 7, tháng 10 năm 2020 và tháng 01 năm 2021. Nhiều loại ngu cu cố định và di động được sử dụng để đảm bảo thu được nhiều loài cá. Các mẫu cá được định danh, cân ( $\mathrm{g} / \mathrm{cá}$ thể) và đo chiều dài $(\mathrm{cm})$. Bên cạnh đó, các chì số phong phú loài Margalef (d), chi số đa dạng Simpson (1-D) và chỉ số đa dạng loài Shannon - Wiener ( $\left.H^{\prime}\right)$ được tính toán để đánh giá mức đô đa dạng sinh học. Kết quả cho thấy việc thiếu nước ngọt trong mùa khô là mối đe dọa cá ở vùng lõi. Tổng số 32 loài cá thuộc 6 bộ và 17 họ được xác định. Vùng lõi có tính đa dạng, ổ định hơn so với vùng đệm ở các sinh cảnh và thời gian khác nhau, nhưng có sụ biến động theo mực nước. 


\section{GIỚI THIÊU}

Đa dạng sinh học có vai trò quan trọng đối với sự sống trên trái đất, cung cấp nguồn tài nguyên sinh vật, lương thực và thực phẩm cho con người ( $\mathrm{FAO}$, 2019), là nền tảng cho việc duy trì các hệ sinh thái, đa dạng sinh học ngày càng có ý nghĩa quan trọng đảm bảo năng suất bền vững cho sự sống trên toàn cầu (Altieri, 2002). Trước tình hình tăng dân số, không gian sống ngày càng bị thu hẹp, nhu cầu thâm canh hóa trong canh tác sản xuất nông nghiệp diễn ra nhiều nơi, dư lượng thuốc và hóa chất trong canh tác đã tác động đến môi trường và động vật hoang dã, do giảm dần không gian sống cho hệ động thực vật (Bianchi et al., 2006), nhiều loài có nguy cơ diệt vong do thiếu môi trường sống, không còn chỗ tìm thức ăn, cư trú, nơi sinh sản bị biến mất, bị khai thác quá mức (Bailey \& Lazarovits, 2003).

Do đó, việc duy trì bảo vệ không gian sống của động vật hoang dã ngày càng cấp thiết, đặc biệt là sinh vật thuộc hệ sinh thái nước ngọt, nguy cơ bị diệt vong ngày càng cao, trước tình hình biến đổi khí hậu, xâm nhập mặn làm cho hệ sinh thái nước ngọt có xu hướng thu hẹp dần và nguy cơ biến mất (Taylor et al., 2016). Cá nước ngọt là một trong những nhóm động vật thủy sinh có vai trò quan trọng về mặt sinh thái, có giá trị kinh tế cao, là thực phẩm ưa chuộng của con người. Ngoài ra, chúng là mắt xích không thể thiếu trong chuỗi thức ăn trong hệ sinh thái, là cầu nối giữa các nhóm loài sinh vật tiêu thụ khác nhau, có vai trò cân bằng hệ sinh thái, cá làm thức ăn cho các loài cá khác, thú, lưỡng thê, bò sát và chim. Do đó, sự biến mất hay xuất hiện loài cá này sẽ ảnh hưởng đến sự phát triển hay tồn tại của các loài khác (FAO, 2019).

Vườn quốc gia (VQG) U Minh Thượng (UMT) là một trong những khu hệ sinh thái nước ngọt rừng tràm trên đất than bùn còn sót lại ở Việt Nam và thế giới (Lê Phát Quới và Vũ Ngọc Long, 2012), với tổng diện tích khoảng 21.122 ha tọa lạc trên 2 xã: Minh Thuận và An Minh Bắc, huyện U Minh Thượng, tỉnh Kiên Giang bao gồm 8.053 ha vùng lõi và 13.069 ha vùng đệm bao quanh (Thủ tướng Chính phủ, 2002). Các thông tin về hiện trạng nguồn lợi cá, thành phần loài cá, mức độ đa dạng sinh học ở VQG còn hạn chế, chưa đồng nhất về số loài giữa các tác giả khác nhau, do phạm vi và thời gian nghiên cứu khác nhau. Bùi Hữu Mạnh (2012) xác nhận có 64 loài cá, trong khi đó Bộ Tài nguyên và Mồi trường (2016) báo cáo có 32 loài cá trong vùng lõi VQG UMT, còn theo Phạm Văn Tùng (2017), có 37 loài cá trong khu vực này. Vì vậy, mục tiêu nghiên cứu này nhằm phân tích về hiện trạng nguồn lợi cá ở vùng lõi VQG UMT bao gồm: (i) xác định hiện trạng quản lý nước và nguồn lợi cá ở vùng lõi $\mathrm{VQG}$ UMT, (ii) xác định thành phần loài, và (iii) mức độ đa dạng sinh học ở vùng nghiên cứu để làm cơ sở cho các giải pháp quản lý tốt hơn trong việc duy trì tính đa dạng sinh học VQG theo hướng bền vững.

\section{PHƯƠNG PHÁP NGHIÊN CÚU}

\subsection{Vùng nghiên cứu}

VQG UMT được thành lập năm 2002 theo Quyết định số 11/2002/QĐ-TTg của Thủ tướng Chính phủ. Năm 2016, VQG được công nhận là khu Ramsar thứ 2.228 của thế giới và thứ 8 của Việt Nam, là một trong những nơi có đa dạng sinh học cao ở Đồng bằng sông Cửu Long (ĐBSCL) (Nguyễn Hằng, 2016). VQG UMT là vùng đất ngập nước thông nhau có các kiểu sinh cảnh trảng đầm lầy bèo lục bình, súng, bồn bồn, kênh, trảng trống theo mùa, được bao bọc bởi hệ thống đê khép kín (Safford et al., 1998).

Theo Võ Tòng Anh (2013) thì vùng lõi VQG UMT có các hệ sinh cảnh như: Rừng tự nhiên trên đất than bùn $(666,45 \mathrm{ha})$; Rừng tràm tái sinh trên đất sét (2.688,3 ha); Rừng tràm tái sinh trên đất than bùn (2.489,3 ha); Sậy (1.025,0 ha); Kênh và mặt nước trống $(1.169,0$ ha), vì sự phong phú các sinh cảnh đặc trưng tạo điều kiện tốt cho sự phát triển khu hệ cá nơi đây so với các vùng ngập nước khác ở ĐBSCL.

\subsection{Phương pháp thu số liệu}

\section{Thu thập số liệu thứ cấp}

Nghiên cứu sử dụng thông tin từ tài liệu, báo cáo, các công trình nghiên cứu khoa học trong và ngoài nước liên quan đển tình hình quản lý nước, thủy sản, thành phần loài cá ở ĐBSCL và các nghiên cứu ở VQG UMT để so sánh, phân tích, thảo luận.

\section{Thu thập số liệu sơ cấp}

\section{Phương pháp thu mẫu thành phần loài cá}

- Thu mẫu cá để xác định thành phần loài từ tháng 5 năm 2020 đến tháng 01 năm 2021, có 4 đợt thu mẫu ở tháng 5 , tháng 7 , tháng 10 năm 2020 và tháng 01 năm 2021.

- Dựa trên dữ liệu thứ cấp và kết hợp thông tin từ cán bộ quản lý VQG UMT đã chọn 5 hệ sinh cảnh chính. Mỗi đợt thu có 15 điểm bao gồm 3 điểm x 4 sinh cảnh ở vùng lõi và 1 điểm $x 3$ vị trí thu mẫu ở vùng đệm, các hệ sinh cảnh ở vùng lõi như (i) trảng bèo - lục bình, (ii) trảng súng; (iii) rừng tràm ngập nước, (iv) kênh và (v) vùng đệm. Vị trí thu mẫu cá được thể hiện ở Hình 1. 
- Các ngư cụ di động: chài, lưới kéo và vợt xúc. Các ngư cụ này được dùng để thu mẫu cá nhỏ, nơi không gian hẹp không thể dùng ngư cụ cố định được, thu 2 ngày/ đợt, mỗi ngày 2 lần vào buổi sáng từ 7:00 10:00 am và buổi chiều từ 2:00 5:00 pm mắt lưới ngư cụ từ $17 \mathrm{~mm}-70 \mathrm{~mm}$. Tại mỗi điểm thu bằng nhiều ngư cụ khác nhau bảo đảm thu ở các tầng nước khác nhau. Thời gian và cách thu mẫu các đợt là như nhau.

\section{Bảng 1. Các loại ngư cụ di động}

\begin{tabular}{clllll}
\hline \multicolumn{2}{l}{ STT Ngư cụ Kích cõ̃ dài $\mathbf{x}$ rộng $(\mathbf{m} \times \mathbf{~} \mathbf{m})$} & Mắt lưới $(\mathbf{m m})$ & Số lượng Nơi đặt \\
\hline 1 & Chài & Đường kính $4,0 \mathrm{~m}$ & 15 và 20 & 2 & Kênh, trảng trống \\
\hline 2 & $\begin{array}{l}\text { Lưới } \\
\text { kéo }\end{array}$ & $4,0 \mathrm{~m} \times 1,5 \mathrm{~m}$ & 5 và 10 & 2 & $\begin{array}{l}\text { Kênh, trảng nơi có thực vật thủy sinh } \\
\text { (không gian hẹp) }\end{array}$ \\
\hline 3 & Vợt xúc Đường kính $0,6 \mathrm{~m}$ và $1 \mathrm{~m}$ & 5,10 và 15 & 3 & $\begin{array}{l}\text { Kênh, trảng nơi có thực vật thủy sinh } \\
\text { (không gian hẹp) }\end{array}$ \\
\hline
\end{tabular}

- Các ngư cụ cố định: lưới rê 3 màng, dớn, lợp, lú. Các loại ngư cụ này được sử dụng để thu mẫu cá Bảng 2. Các loại ngư cụ cố định

\begin{tabular}{|c|c|c|c|c|c|}
\hline STT & Ngư cụ cố định & $\begin{array}{l}\text { Kích cõ̃ } \\
\text { dài } x \text { rộng (m x m) }\end{array}$ & $\begin{array}{l}\text { Mắt lưới } \\
(\mathrm{mm})\end{array}$ & Số lượng & Nơi đặt \\
\hline 1 & Lưới rê 3 màng & $150 \times 2,0$ & 35 và 70 & $150 \mathrm{~m}$ & Kênh \\
\hline 2 & Lưới rê 3 màng & $150 \times 1,0$ & 35 và 70 & $150 \mathrm{~m}$ & Kênh, trảng trống ngập nước \\
\hline 3 & Lợp & $\begin{array}{l}\text { Dài } 0,8 \mathrm{~m} \text {; } \\
\text { đường kính } 0,3 \mathrm{~m}\end{array}$ & 20 & 10 cái & $\begin{array}{l}\text { Gốc cây, bụi, nơi có giá thể } \\
\text { lớn }\end{array}$ \\
\hline 4 & Dớn & 10 m cánh & 1 và 2 & 10 cái & $\begin{array}{l}\text { Kênh, trảng trống, trảng có } \\
\text { thực vật thủy sinh }\end{array}$ \\
\hline 5 & Lú & $3 \mathrm{~m}$ & 1 và 2 & 10 cái & $\begin{array}{l}\text { Kềnh, trảng trống, trảng có } \\
\text { thực vật thủy sinh }\end{array}$ \\
\hline
\end{tabular}

- Tất cả các mẫu sau khi thu được phân loại sơ bộ theo từng vị trí thu mẫu, được bảo quản lạnh và formaline $10 \%$ và mang về Phòng thí nghiệm nguồn lợi, Khoa Thủy sản, Trường Đại học Cần Thơ để định danh, cân đo và đếm số lượng cho từng loài/ thủy vực qua mỗi đợt thu. Việc định danh được thực hiện dựa trên hệ thống phân loại hình thái học của Trần Đắc Định và ctv. (2013). với tần suất 8 giờ thu 1 lần, thời gian là 2 ngày 2 đêm/đợt.

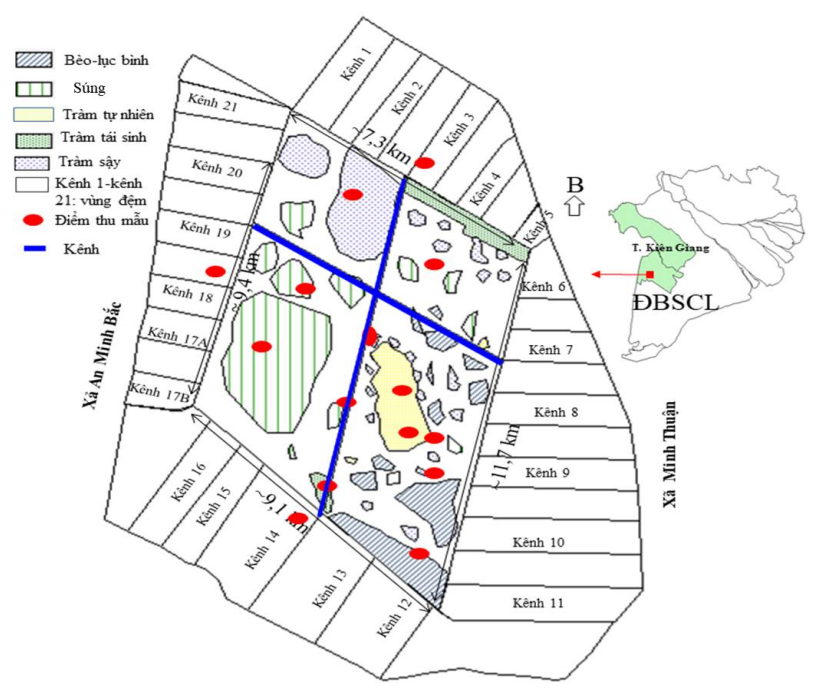

Hình 1. Bản đồ các điểm thu mẫu cá ở VQG U Minh Thượng 


\subsection{Xử lý số liệu}

- Số liệu khảo sát từ các cán bộ kỹ thuật, cán bộ quản lý được vẽ sơ đồ kết hợp phân tích.

- Các số liệu thành phần loài theo đợt, sinh cảnh được thống kê bằng chương trình Microsoft Excel, mô tả tần suất xuất hiện của các loài cá theo mùa.

- Các chỉ số đa dạng là biểu thị độ phong phú loài trong môi trường quan sát, chúng được sử dụng để đánh giá 3 khía cạnh của cấu trúc quần xã: Số lượng loài, số lượng cá thể mỗi loài và tổng số cá thể thu được.

- Chỉ số phong phú loài Margalef (d): được sử dụng để xác định tính đa dạng (độ phong phú) về loài, chỉ số cho biết tính đa dạng loài và tính đồng đều giữa các loài và số lượng cá thể của quần xã (Daly et al., 2018). Công thức tính:

$$
d=\frac{S-1}{\operatorname{LnN}}
$$

Trong đó, d: chỉ số phong phú $\mathrm{S}$ là tổng số loài; $\mathrm{N}$ là tổng số cá thể; $\mathrm{d}$ càng lớn thì tính đa dạng càng cao.

- Chỉ số ưu thế Simpson (D): được sử dụng để đo lường sự đa dạng của một quần xã. Nó thường được sử dụng để đo lường đa dạng sinh học, được dùng để xác định đại diện cho loài ưu thế, $\mathrm{D}$ càng nhỏ thì tính đa dạng sinh học càng cao (Okpiliya, 2012), công thức tính:

$$
D=\frac{\sum_{i=1}^{n} n i(n i-1)}{N(N-1)}
$$

- Chỉ số đa dạng Simpson (1-D): giá trị $0 \leq$ $1-\mathrm{D} \leq 1$. Giá trị này càng tiến về 0 thì càng kém đa dạng và càng tiến về 1 thì càng đa dạng; Trong đó: ni là số lượng loài thứ i; $\mathrm{N}$ là tổng số cá thể của tổng số loài thu được; $\mathrm{D}$ là chỉ số ưu thế Simpson. Chỉ số đa dạng Simpson thể hiện mức độ phong phú của loài. Chỉ số này được sử dụng trong việc theo dõi nghiên cứu đa dạng sinh học, không những đo về mức độ đa dạng mà xem xét cả mức độ phong phú và tính đồng đều (Somerfield et al., 2008).

- Chỉ số đa dạng loài Shannon - Wiener (H'): Thể hiện sự đa dạng loài trong quần xã, chỉ số này không phải chỉ phụ thuộc vào thành phần số lượng loài mà cả số lượng cá thể và xác suất xuất hiện của các cá thể trong mỗi loài (Bibi and Ali, 2013), công thức tính:

$$
\left(H^{\prime}\right)=-\sum_{i=1}^{n} \frac{n i}{N} * \operatorname{Ln}\left(\frac{n i}{N}\right)
$$

Trong đó: H' là chỉ số đa dạng Shannon; ni là số lượng cá thể của loài thứ $i$; $n$ là tổng số loài trong quần thể; $\mathrm{N}$ là tổng số cá thể của tất cả các loài thu được. Chỉ số Shannon thuận lợi khi xem xét số loài và mức độ đồng đều của các loài. Theo Seaby và Henderson (2007) phạm vi giá trị tính đa dạng sinh học theo các cấp như sau: $>3,5$ : tính đa dạng rất phong phú; Từ 2,6 3,5: tính đa dạng phong phú; Từ 1,6 2,5: tính đa dạng tương đối tôt; Từ $0,6 \sim$ 1,5 : tính đa dạng bình thường; và $<0,6$ : tính đa dạng kém.

\section{KẾT QUẢ}

\subsection{Hiện trạng quản lý nước và nguồn lọ̣i cá trong VQG U Minh Thượng}

Kết quả khảo sát cho thấy VQG UMT là khu bảo tồn đất ngập nước, việc giữ rừng chống cháy là ưu tiên hàng đầu làm cơ sở cho việc duy trì tính đa dạng sinh học. Do đó, nếu nước lợ mặn vào VQG sẽ ảnh hưởng đến hệ sinh thái nước ngọt, việc duy trì hệ thống đê bao để giữ nước mưa là quan trọng. Ngoài ra, kết quả nghiên cứu cho thấy không có sự khác biệt rõ ràng cho từng loại sinh cảnh ở vùng lõi như: kênh mương vẫn có súng sen, lục bình, bèo; vùng tràm vẫn có súng sen; kênh, trảng và vùng đệm vẫn có kênh mương, trảng súng sen và lục bình. Bên cạnh đó, trảng có diện tích lớn nên có sự di chuyển của bèo và lục bình trên trảng rất rõ, sự thay đổi này phụ thuộc vào hướng gió.

Theo kết quả phỏng vấn mở các cán bộ quản lý VQG UMT và khảo sát thực tế: Vùng lõi nơi này được bao quanh bởi hệ thống kênh bao khép kín nhằm duy trì hệ sinh thái nước ngọt và ngăn chặn xâm nhập mặn mùa khô. Nơi đây có các cống điều tiết để điều chỉnh mực nước. Nguồn nước cấp cho VQG chủ yếu là từ nước mưa, khu vực xung quanh vùng lõi bị nhiễm mặn mùa khô nên công tác bảo vệ hệ sinh thái nước ngọt càng khó khăn hơn. Trong đó, cá ở VQG UMT bị ảnh hưởng bởi điều kiện bất lợi khách quan có thể kể đến như sau (Hình 2):

(i) Thiếu nguồn nước ngọt vào mùa khô (tháng 2 - tháng 5 hàng năm) làm cá chết cạn nhiều ở các trảng lớn, số cá còn lại rút xuống kênh nơi nước còn sót lại tạo nên mật độ cao, chúng phải duy trì sự sống trong môi trường sống khắc nghiệt này để tồn tại. Đây là thời điểm nhóm thú, bò sát, chim tập trung lại các nơi có nước (trũng) uống nước và săn mồi mà chủ yếu là cá cạn dẫn đến mất cân bằng trong quần xã.

(ii) Môi trường bất lợi: theo lãnh đạo quản lý VQG thì kết quả quan trắc mực nước từ năm 1999 đến nay cho thấy mực nước hạ xuống mức rất thấp 
so với yêu cầu giữ ẩm cho đất vào mùa khô. Điều này ảnh hưởng rất lớn đến nguồn lợi thủy sản do không gian sống hẹp dần, nhiệt độ tăng cao. Do đó, cá thường xuyên tập trung xuống các kênh, thường chết do mắc cạn. Lúc này, các loài chim, cò và thú bắt cá (rái cá) cũng tập trung lại nơi đây uống nước và săn bắt mồi làm ảnh hươ̛ng nghiêm trọng đến nguồn lợi cá ở nơi này.

(iii) Mất cân bằng quần xã: Theo cán bộ VQG, 1-2 năm gần đây quần thể cá lóc bông (Channa micropeltes) tăng dần. Đây là loài cá dữ, có tập tính sinh sản, giữ con rất tốt, nên tỷ lệ sống cao. Việc gia tăng quần thể này làm ảnh hưởng rất lớn đến tình hình quản lý thủy sản ở VQG và làm mất cân bằng trong cấu trúc hệ sinh thái ở rừng tràm. (iv) Tình trạng khai thác thủy sản: Ở vùng lõi VQG có dịch vụ câu cá giải trí từ năm 2004, để phục vụ du lịch và góp phần tăng nguồn ngân sách cho Nhà nước. Theo lãnh đạo VQG, dịch vụ này không ảnh hưởng đến nguồn lợi cá do được quản lý chặt chẽ ngư cụ và thời gian câu cá. Tuy nhiên, có $40 \%$ người trả lời cho rằng dịch vụ câu cá này sẽ có ảnh hưởng đến cơ cấu quần đàn cá và chuỗi thức ăn trong hệ sinh thái vì loại cá được khai thác thường là cá cỡ lớn (cá lóc, cá trê vàng) đang trong giai đoạn thành thục sinh sản hoặc đang giữ con. Bên cạnh đó, sinh kế cộng đồng bị ảnh hưởng, vào mùa khô, họ vào vùng lõi khai thác tài nguyên trái phép là khó tránh khỏi do dễ khai thác cá cạn (thay vì cá cạn cần được cứu hộ, thì chúng bị săn bắt dễ dàng bởi con người và động vật săn mồi).

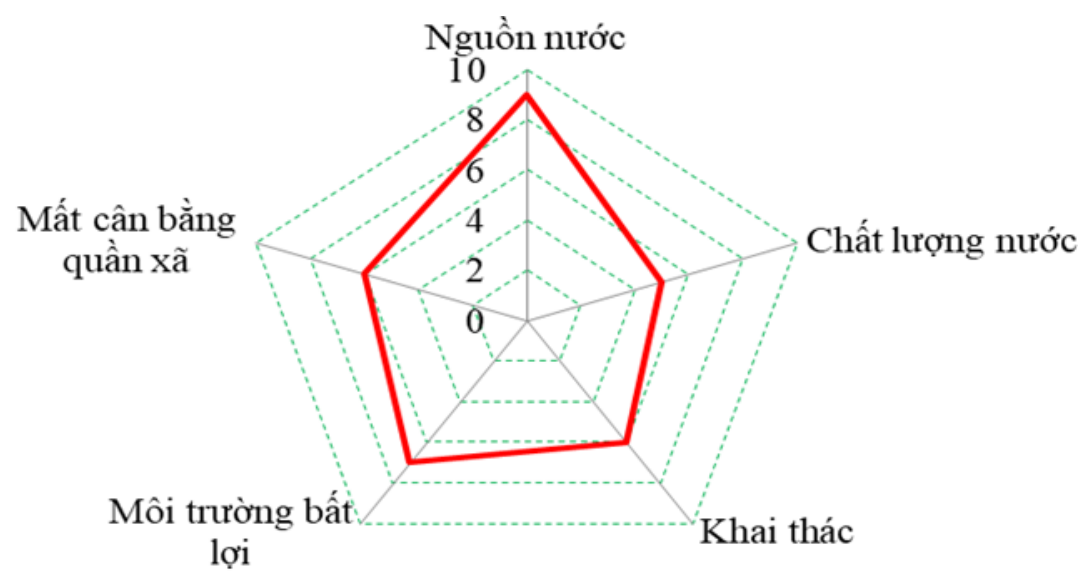

Hình 2. Một số vấn đề ảnh hưởng đến nguồn lợi thủy sản ở Vùng lõi VQG UMT theo mức độ (từ 0: ít ảnh hưởng đến 10: ảnh hưởng nhiều)

\subsection{Thành phần loài cá qua các đột thu mẫu}

Kết quả nghiên cứu đã thu được 32 loài cá thuộc 6 bộ và 17 họ cá qua 4 đợt khảo sát. Trong đó, bộ cá vược (Perciformes) chiếm số lượng cao nhất với 7 họ $(41 \%)$, tiếp theo là bộ cá da trơn (Siluriformes) và bộ lươn (Synbranchiformes) với 3 họ (18\%), các bộ cá còn lại có số lượng từ 1 đến 2 họ chiếm $6 \%$ đển $12 \%$. Họ Cyprinidae nhiều nhất với 9 loài $(28 \%)$, tiếp theo là họ Osphronemidae với 5 loài $(16 \%)$, họ Channidae 3 loài $(9 \%)$, họ Clariidae 2 loài (6\%) và các họ khác mỗi họ chỉ có 1 loài.
Số lượng loài cá được sắp xếp và đánh dấu theo hai mùa: mùa khô (tháng $5 / 2020$; tháng $01 / 2021$ ) và mùa mưa (tháng 7; tháng 10 năm 2020). Cấu trúc thành phần loài cá theo bộ, họ và loài được tính bằng tỉ lệ phần trăm. Mức độ phong phú của mỗi loài được ghi nhận sau mỗi lần thu mẫu, được tính chung cho tất cả các sinh cảnh. Qua kết quả Bảng 3 , các loài cá phân bố theo mùa với số lượng rất ít $(+)$, tần số xuất hiện ở cả hai mùa rất thấp $(<30 \%)$. Trong đó, sự phân bố của các loài cá thu được theo mùa không có sự chênh lệch đáng kể ở mùa khô (26 loài) và mùa mưa (27 loài). 
Bảng 3. Mức độ phong phú loài cá vùng lõi VQG U Minh Thượng phân bố theo mùa

\begin{tabular}{|c|c|c|c|c|}
\hline STT & Tên khoa học & Tên Tiếng việt & $\begin{array}{c}\text { Mùa } \\
\text { khô }\end{array}$ & $\begin{array}{l}\text { Mùa } \\
\text { mưa }\end{array}$ \\
\hline & Beloniformes & Bộ Cá lìm kìm & & \\
\hline (1) & Adrianichthyidae & Họ Cá sóc & & \\
\hline 1 & Oryzias minutillus (Smith, 1945) & Cá sóc & & + \\
\hline (2) & Hemiramphidae & Họ Cá lìm kìm & & \\
\hline 2 & Dermogenys siamensis (Fowler, 1934) & Cá lìm kìm ao & + & + \\
\hline & Cypriniformes & Bộ Cá chép & & \\
\hline (3) & Cyprinidae & Họ Cá chép & & \\
\hline 3 & Parachela siamensis (Günther, 1868) & Cá lành canh xiêm & + & + \\
\hline 4 & Paralaubuca typus (Bleeker, 1864) & Cá thiểu mẫu & & + \\
\hline 5 & Rasbora borapetensis (Smith, 1934) & $\begin{array}{l}\text { Cá lòng tong đuôi } \\
\text { đỏ }\end{array}$ & + & + \\
\hline 6 & Boraras urophthalmoides (Kottelat, 1991) & Cá lòng tong đỏ & + & + \\
\hline 7 & Puntius brevis (Bleeker,1849) & Cá rằm & & + \\
\hline 8 & Hampala dispar (Smith, 1934) & Cá ngựa nam & & + \\
\hline 9 & Hampala macrolepidota (Kuhl \& Van Hasselt, 1823) & Cá ngựa & + & + \\
\hline 10 & Cyclocheilichthys apogon (Valenciennes, 1842) & Cá ba kỳ đỏ & + & + \\
\hline 11 & $\begin{array}{l}\text { Amblypharyngodon chulabhornae (Vidthayanon \& } \\
\text { Koteelat, 1990) }\end{array}$ & Cá tráo & + & + \\
\hline & Osteoglossifornes & Bộ Cá thát lát & & \\
\hline (4) & Notopteridae & Họ Cá thát lát & & \\
\hline 12 & Notopterus notopterus (Pallas, 1769) & Cá thát lát & + & + \\
\hline IV. & Perciformes & Bộ Cá vược & & \\
\hline (5) & Drepaneidae & Họ Cá hiên & & \\
\hline 13 & Pritolepis fasciata (Bleeker, 1851) & Cá rô biển & + & + \\
\hline (6) & Cichlidae & Họ Cá rô phi & & \\
\hline 14 & Oreochromis niloticus (Linnaeus, 1758) & Cá rô phi vằn & + & + \\
\hline (7) & Anabantidae & Họ Cá rô & & \\
\hline 15 & Anabas testudineus (Bloch, 1792) & Cá rô đồng & + & + \\
\hline (8) & Osphronemidae & Họ Cá tai tượng & & \\
\hline 16 & Trichopodus trichopterus (Pallas, 1770) & Cá sặc bướm & + & + \\
\hline 17 & Betta splendens (Regan, 1910) & Cá lia thia xiêm & + & + \\
\hline 18 & Trichopsis vittata (Cuvier, 1831) & Cá bãi trầu & + & + \\
\hline 19 & Trichopodus pectoralis (Regan, 1910) & Cá sặc rằn & + & + \\
\hline 20 & Trichopsis pulima (Arnold, 1936) & Cá bãi trầu lùn & + & \\
\hline (9) & Channidae & Họ Cá lóc & & \\
\hline 21 & Channa striata (Bloch, 1793) & Cá lóc đen & + & + \\
\hline 22 & Channa lucius (Cuvier, 1831) & Cá dày & + & + \\
\hline 23 & Channa micropeltes (Cuvier, 1831) & Cá lóc bông & + & \\
\hline$(10)$ & Eleotridae & Họ Cá bống đen & & \\
\hline 24 & Oxyeleotris marmorata (Bleeker, 1852) & Cá bống tượng & + & \\
\hline$(11)$ & Gobiidae & Họ Cá bống trắng & & \\
\hline 25 & Gobiopterus chuno (Hamilton, 1822) & Cá bống chuno & + & + \\
\hline V. & Siluriformes & Bộ Cá da trơn & & \\
\hline$(12)$ & Siluridae & Họ Cá nheo & & \\
\hline 26 & Ompok siluroides (Lacepède, 1803) & Cá trèn bầu & & + \\
\hline$(13)$ & Clariidae & Họ Cá trê & & \\
\hline 27 & Clarias macrocephalus (Günther, 1864) & Cá trê vàng & + & + \\
\hline 28 & Clarias batrachus (Linnaeus, 1758) & Cá trê trắng & + & \\
\hline (14) & Bagridae & Họ Cá ngạnh & & \\
\hline 29 & Mystus mysticetus (Roberts, 1992) & Cá chốt sọc & & + \\
\hline
\end{tabular}




\begin{tabular}{|c|c|c|c|c|}
\hline STT & Tên khoa học & Tên Tiếng việt & $\begin{array}{c}\text { Mùa } \\
\text { khô }\end{array}$ & $\begin{array}{l}\text { Mùa } \\
\text { mưa }\end{array}$ \\
\hline & Synbranchiformes & Bộ mang liền & & \\
\hline$(15)$ & Synbranchidae & Họ Lươn & & \\
\hline 30 & Monopterus albus (Zuiew, 1793) & Lươn đồng & + & + \\
\hline$(16)$ & Chaudhuriidae & Họ Lươn & & \\
\hline 31 & Chaudhuria caudata (Annandale, 1918) & Lươn miến điện & + & + \\
\hline (17) & Mastacembelidae & Họ Cá chạch & & \\
\hline 32 & Macrognathus siamensis (Günther, 1861) & Cá chạch xiêm & + & \\
\hline
\end{tabular}

Chú thich: cách phân chia mức độ xuất hiện (+) tần số xuất hiện $<30 \%$; (++) tần số xuất hiện 30-60\%; (+++) tần số xuất hiện $>60 \%$ (Mai Viết Văn, 2019).

Nhóm cá có giá trị kinh tế như cá lóc, cá rô đồng, cá thát lát, cá trê vàng xuất hiện ở hầu hết các sinh cảnh qua các mùa với tần suất xuất hiện như nhau. Nhóm cá này có khả năng chịu đựng được bất lợi của môi trường như oxy thấp, $\mathrm{pH}$ thấp, thiếu nước. Con non của nhóm cá này xuất hiện nhiều gần cuối mùa mưa vì mùa sinh sản của chúng là đầu và giữa mùa mưa. Cá lớn lên trảng vào rừng vào mùa ngập nước (tháng 10 đến tháng 1 ), khi nước cạn thì xuống kênh mương (tháng 5 - tháng 7).

Về cơ bản là không có thay đổi nhiều về thành phần loài ở các tháng khác nhau, mỗi đợt từ 15 đến

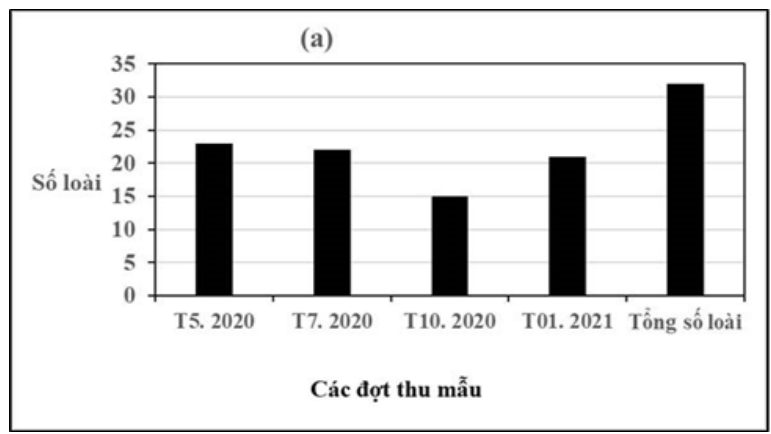

23 loài (Hình 3a; Hình 3b), do cuối mùa mưa (tháng 10) mức nước cao nhất, không gian sống của cá rộng, cá di chuyển lên các trảng và lên rừng tạo mật độ thưa, cá sinh trưởng và phát triển tốt. Trong khi đó, tháng 5 là mùa khô, mức nước cạn nên cá tập trung xuống các kênh sâu nơi còn nước tạo mật độ cao. Lúc này ở rừng tràm và một số trảng đã cạn nước. Như vậy, yếu tố mùa ảnh hưởng đến sự phân bố của loài theo sinh cảnh và số lượng cá non được sinh ra sau mùa mưa.

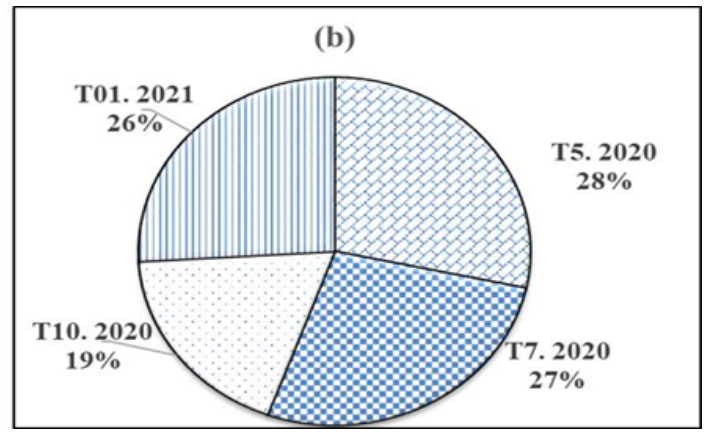

Hình 3. Biến động số lượng loài cá qua các đọ̣t thu mẫu (a);

\section{Tỉ lệ \% loài cá qua các thời điểm thu mẫu (b)}

Cơ cấu số lượng cá có sự khác biệt giữa nhóm kích cỡ của từng loài cá, điều này phụ thuộc vào đặc điểm sinh học của chúng. Nhóm cá kích cỡ nhỏ như cá lành canh xiêm (292 cá thể), cá bãi trầu (227 cá thể), cá lòng tong đuôi đỏ (111 cá thể),... có số lượng lớn. Chúng sinh sản nhiều lần trong năm, phân bố rộng, sống được ở các sinh cảnh khác nhau, chịu được điều kiện khắc nghiệt của môi trường. Nhóm này có vai trò quan trọng trong hệ sinh thái vì chúng ăn những sinh vật có kích cỡ nhỏ, mùn bã hữu cơ, động thực vật phù du, nhưng chúng lại là thức ăn cho nhiều loài cá khác có kích cỡ lớn hơn như nhóm chim và nhiều nhóm loài khác. 


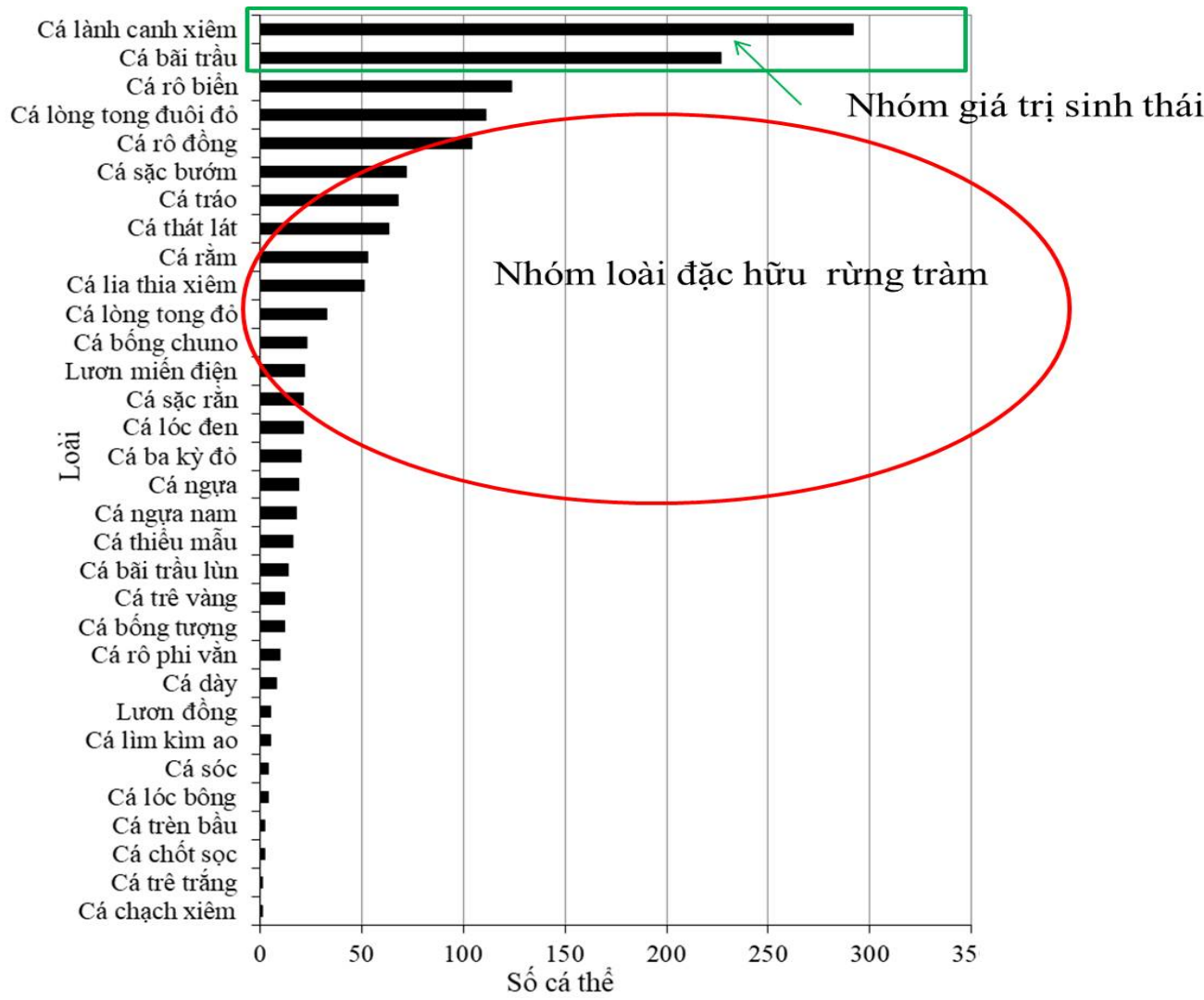

Hình 4. Số lượng cá thể thu được theo loài

Nhóm cá kích cỡ lớn hơn như cá rô biển (124 cá thể), cá rô đồng (104 cá thể), cá sặc bướm (72 cá thể), cá lóc đen (4 cá thể) là những loài đặc hữu của rừng tràm, chiếm tỉ lệ nhất định ở vùng lõi VQG. Chúng chịu được điều kiện bất lợi của môi trường, oxy thấp, sống trong các thủy vực nước tĩnh, đặc biệt ở tầng mặt có bèo lục bình, bông súng nơi tập trung nhiều phiêu sinh vật, là nguồn thức ăn quan trọng cho nhóm cá này (Hình 4).

\subsection{Thành phần loài cá theo sinh cảnh}

Trong tổng số các cá thể thu được theo sinh cảnh và thời gian (Hình $5 \mathrm{a})$, và thành phần phần trăm số loài phân bố theo theo sinh cảnh (Hình $5 \mathrm{~b}$ ), cho thấy không có sự khác biệt về sự phân bố loài theo sinh cảnh và thời gian, chỉ có mức nước trong vùng lõi là yếu tố có ảnh hưởng đến sự khác biệt này, do tháng
5 vẫn còn cạn là đầu mùa mưa nước chưa nhiều, nên cá vẫn tập trung ở các kênh sâu, kênh chính, tháng 7 bắt đầu có nước trên trảng, do có nước mới cá tập trung lên trảng tìm thức ăn trên trảng và mật độ thưa dần do không gian sống được mở rộng. Khu vực rừng tràm có địa hình cao và cạn trong suốt mùa khô (tháng 2 đến tháng 6 ), chỉ ngập nước trong mùa mưa chủ yếu tháng 8 đến tháng 1 . Số cá thể thu được cao nhất ở trảng bèo - lục bình tiếp đó là ở trảng súng do thời điểm này nước cạn, cá tập trung ở các lung trũng, nơi có nhiều sinh vật phù du phát triển, nơi đây tập trung nhiều loài cá cỡ nhỏ (cá bãi trầu, cá lòng tong,...). Vùng đệm là nơi có số lượng cá thể thu được thấp nhất, do là vùng khai thác tự do không được bảo vệ như vùng lõi nên số lượng cá ít hơn. Độ mặn mùa khô lên đến 15 ppt nên có sự xuất hiện của một số loài nước lợ (cá rô phi, cá bống tượng, cá rô biển, cá sặc rằn). 

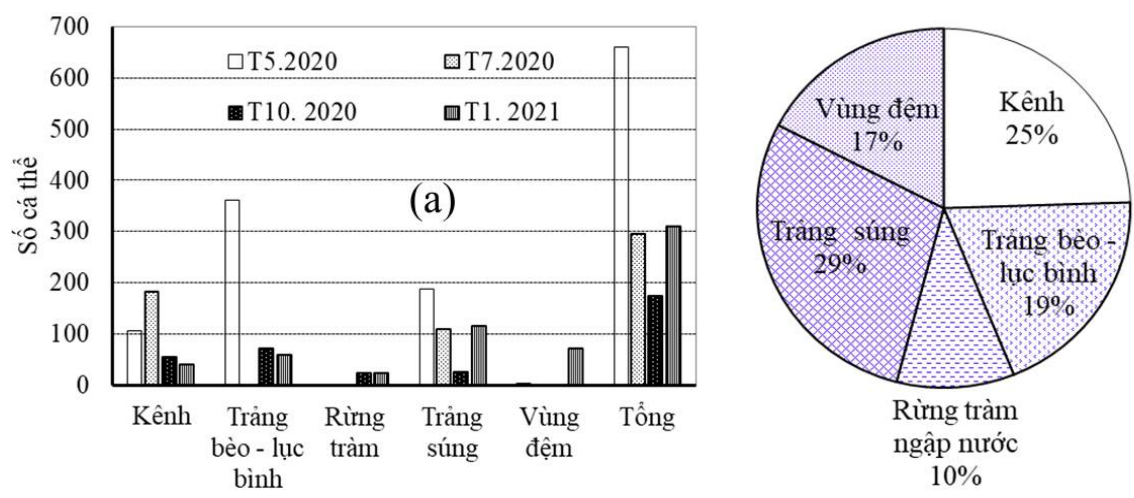

Hình 5. Số cá thể qua các đột thu mẫu ở từng sinh cảnh và thời gian (a);

\section{Thành phần phần trăm số loài theo sinh cảnh (b)}

\subsection{Các chỉ số đa dạng sinh học của cá ở vùng lõi VQG U Minh Thượng}

Nhìn chung không có sự biến động lớn về tính đa dạng thành phần loài ở các sinh cảnh ở các thời điểm khảo sát. Nơi đây các kênh thông với nhau, mức độ đa dạng sinh học ở mức cao và ổn định về
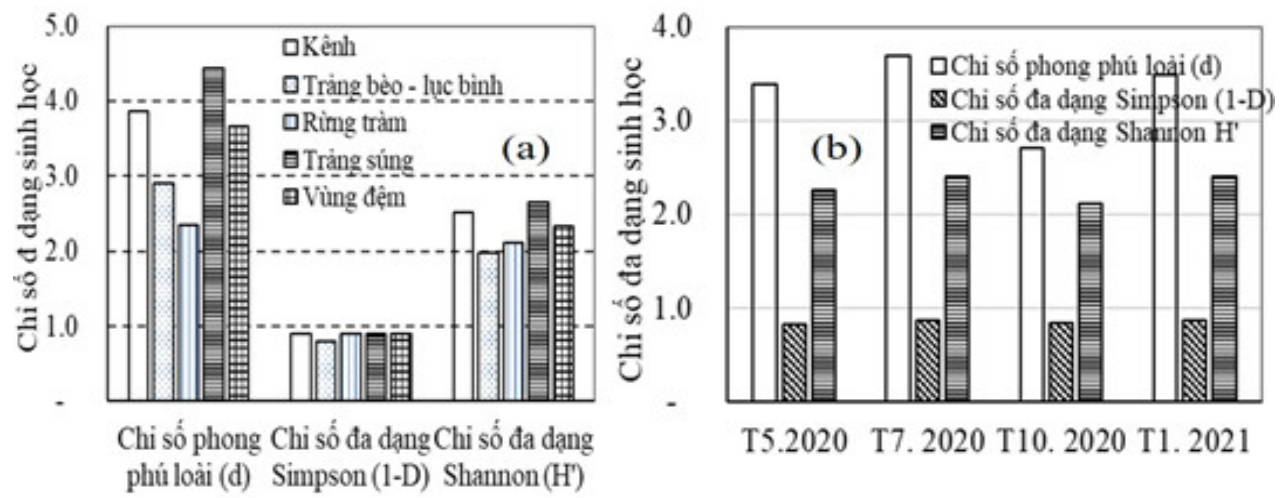

thời gian và không gian qua 3 chỉ số đa dạng (Hình $6 \mathrm{a}$ và Hình $6 \mathrm{~b}$ ): (i) Chỉ số Margalef: 2,5 4,5 cao nhất ở trảng súng và thấp nhất trong rừng tràm là do ảnh hưởng của mức nước; (ii) Chỉ số đa dạng Simpson (1-D) 0,8; (iii) Chỉ số đa dạng Shannon H’: 2,0 2,5 không có sự dao động lớn.

T5.2020 T7. 2020 T10. 2020 T1. 2021

Hình 6. Chỉ số đa dạng sinh học theo sinh cảnh (a) và theo đọ̣t thu mẫu (b)

\section{THẢO LUẬN}

\subsection{Tình hình quản lý nước và nguồn lợi cá ở vùng lõi}

Nguồn nước có vai trò quan trọng trong việc phát triển nguồn lợi thủy sản ở VQG, nhưng theo lãnh đạo quản lý VQG UMT thì nơi đây hoàn toàn không có khả năng nhận nước chủ động từ các nguồn sông rạch bên ngoài, chủ yếu là dựa vào nước mưa. Do đó, nguồn nước ngọt phải tích trữ trong suốt mùa mưa, tháo nước ra ngoài vùng đệm khi nguồn nước trữ đã đầy, nhằm thay đổi nước bên trong vùng lõi và phát tán nguồn cá giống ra vùng đệm để cộng đồng khai thác tận dụng nguồn lợi này. VQG bắt đầu tích nước vào cuối mùa mưa hàng năm khi vùng đệm chưa bị nhiễm mặn. Sau khi trữ nước mưa được hoàn tất các cống sẽ đóng lại, mực nước này cạn dần

do bốc hơi ở mùa khô (tháng 3 và tháng 4 , trước khi bước vào mùa mưa năm sau). Nếu thời tiết khô hạn nắng nóng, mực nước sẽ hạ thấp nhanh hơn làm khô trảng và kênh trong vùng lõi VQG, ảnh hưởng đến nguồn lợi thủy sản.

Việc duy trì đa dạng nguồn lợi cá trong vùng lõi là rất quan trọng trong việc duy trì tính đa dạng sinh học ở VQG. Tuy nhiên, công tác quản lý gặp nhiều khó khăn như hạn hán kéo dài trong mùa khô, vì nguồn nước ngọt nơi đây phụ thuộc vào nước mưa (Phạm Văn Tùng, 2017), lượng nước được tích trữ ở cuối mùa mưa năm trước, khi hạn hán, nhiệt độ cao làm nước bốc hơi mạnh dẫn đến cạn kiệt nguồn nước sớm hơn. Đặc điểm cây tràm là loài cây chịu được ngập nhưng không phải là loài cây ưa ngập, nhiều nơi cây tràm bị chết, đổ gãy hàng loạt khi ngập nước trên 6 tháng, khi đó rừng không còn sức sống, 
chim thú mất nơi trú ngụ, nghĩa là nơi ngập nước sâu là nơi cây tràm kém phát triển. Điều này mâu thuẫn với việc phát triển nguồn lợi cá trong VQG (Trần Quang Bảo \& Phạm Văn Duẩn, 2011; Trần Văn Thắng, 2016), do đó việc duy trì nước tạo không gian sống cho các loài cá cũng ở giới hạn nhất định, mùa vụ sinh sản của hầu hết các loài cá nước ngọt (cá đồng) là đầu mùa mưa, trong khi đầu mùa mưa ở vùng lõi cá vừa qua cơn sống sót, hao hụt nhiều do sống trong môi trường khắc nghiệt, thiếu thức ăn, cá nhỏ bị chết cạn và chim chóc săn bắt, cá lớn thiếu thức ăn, do đó cần có thời gian để tích trữ năng lượng cho việc sinh sản, khi đó thời gian cá bắt đầu sinh sản bị trễ hơn so với quy luật (đầu mùa mưa). Khi con non được nở ra và độc lập sinh trưởng là gần cuối mùa mưa, chúng lại phải trải qua mùa khô sắp tới, quá trình cứ lặp lại hàng năm, nhưng việc mở rộng không gian, đào thêm kênh mương trũ nước lại là quy định của ngành lâm nghiệp rất phức tạp, do đó phải hài hòa giữa các bên trong hệ sinh thái. Vì vậy, theo lãnh đạo VQG là giữ nguyên hiện trạng.

Ngoài ra, do sinh kế cộng đồng ở vùng đệm gặp nhiều khó khăn, nghèo đói, mất mùa, thất nghiệp, những người này sẽ có xu hướng vào vùng lõi VQG khai thác trái phép tài nguyên, điều này có tác động trực tiếp và gián tiếp đến việc bảo vệ tài nguyên ở VQG (Lê Tấn Lợi \& Lý Trung Nguyên, 2015; Trần Văn Việt và ctv., 2020).

\subsection{Thành phần loài cá ở vùng lõi}

Số loài cá ở VQG UMT có sự chênh lệch giữa các nghiên cứu, kết quả nghiên cứu này thu được 32 loài cá ở vùng lõi, trong khi đó theo Vũ Nguyễn Hoàng Giang và Trần Bá Hoàng (2016), Lương Văn Thanh và Phạm Văn Tùng (2011) thì ở VQG UMT có tổng số 37 loài cá (15 loài không kinh tế và 22 loài có giá trị kinh tế). Ngoài ra, có một số nghiên cứu công bố ở VQG UMT có loài nước lợ, một số loài sống môi trường nước chảy, sống mặt nước lớn như hạ lưu sông Mekong, sông Chao Praya, Thái Lan, sông Đồng Nai, như nghiên cứu của Bùi Hữu Mạnh (2012) trong VQG UMT có 64 loài cá nhưng kết quả này chỉ có tính tham khảo do nghiên cứu chủ yếu là điều tra, phỏng vấn cộng đồng vùng đệm; Theo Nguyễn Thị Ngọc Trân và ctv. (2020) thì trong số 64 loài trong báo cáo của Bùi Hữu Mạnh (2012), có 27 loài cá nước lợ thu ở vùng khác, không phải khu vực VQG UMT.

Theo Trần Văn Thắng (2016), VQG UMT có 62 loài cá, cách tiếp cận theo nguyên tắc kế thừa các báo cáo từ các kêt quả nghiên cứu trước và thu thêm các loài cá kinh tế vào mùa khô tháng 4 khi nước rút xuống các kênh. Vì vậy, trong danh sách các loài cá của Trần Văn Thắng (2016) có 1 số loài cá nước mặn/ lợ như cá đối (Liza sp). Theo Tran et al. (2016), ở Việt Nam, có 3 loài cá đối nhưng chúng sống ở nước lợ mặn, kết quả này có thể là kế thừa từ điều tra của Bùi Hữu Mạnh (2012). Tương tự, kết quả của Trần Văn Thắng (2016) có cá hường vện (Datnioides quadrifasciolatus), cá ngát (Plotosus canius) và cá tra (Pangasianodon hypophthalmus), tuy nhiên theo Nguyễn Xuân Đồng và Kiên Thái Bích Nga (2014), cá hường vện là loài cá sống ở sông lớn, nơi có dòng chảy. Theo Rainboth (1996) thì loài này là nước lợ sống ở độ mặn 10 - 20 ppt, đôi khi độ mặn thấp hơn, vì vùng lõi là hoàn toàn nước ngọt, nước tĩnh nên rất hiếm các loài này. Cá ngát (Plotosus canius) là loài sống tầng đáy ở nước ngọt, nước lợ và mặn, nhưng chủ yếu là vùng hạ lưu mặt nước lớn như: sông lớn, vùng cửa sông, ven biển. Theo Hossain and Alam (2015), thì khả năng cá ngát sống trong vùng tĩnh là rất thấp.

Ngoài ra, nghiên cứu ở vùng đệm vào mùa mưa khu vực VQG UMT của Nguyễn Thị Ngọc Trân và ctv. (2020) phát hiện có 54 loài cá không thấy cá đối ở vùng đệm, do mùa mưa nước ngọt, điều này chứng tỏ là sự hiện diện của loài phụ thuộc vào điều kiện môi trường tại thời điểm đó. Trong nghiên cứu này cũng không thấy cá hường vện, cá ngát và cá tra ở vùng đệm. Tuy nhiên, ở vùng đệm có xuất hiện số lượng rất ít $(+)$ cá heo vạch (Yasuhikotakia modesta), cá cóc (Cyclocheilichthys lagleri), cá ét mọi (Labeo chrysophekadion). Đây là những loài cá sông, sống thủy vực lớn và phụ thuộc nước lũ, lưu vực sông Mekong, Biển hồ Campuchia, và sông Chao Phraya của Thái Lan, nhưng một số nghiên cứu báo cáo có phân bố các loài này ở VQG nhưng nghiên cứu này không bắt gặp.

Nhìn chung, do nhiều nguyên nhân khách quan dẫn đến sự khác biệt kết quả nghiên cứu, thời điểm nghiên cứu chênh lệch khoảng 10 năm, phương tiện, dụng cụ, địa điểm không đồng nhất, bản thân người thực hiện và cách tiếp cận cũng khác nhau. Bên cạnh đó, yếu tố thời tiết khí hậu hàng năm cũng khác nhau, có năm hạn hán kéo dài, có năm mùa mưa đến sớm, lũ lụt (năm 2020) điều này cũng ảnh hưởng đến kết quả nghiên cứu. Không chỉ ở VQG UMT mà ở VQG Tràm Chim cũng tương tự về thành phần loài cá, Vũ Nguyễn Hoàng Giang và Trần Bá Hoàng (2016) báo cáo ở VQG Tràm Chim có 107 loài cá chiếm $1 / 4$ loài cá ở ĐBSCL, trong khi Đỗ Thị Như Uyên và Hoàng Thị Nghiệp (2013) thì ở VQG Tràm Chim có 133 loài và Trần Đắc Định và ctv. (2020) báo cáo có 68 loài cá. 


\subsection{Mức độ đa dạng sinh học ở vùng lõi}

Số lượng cá ở VQG UMT có sự phân đàn theo nhóm kích cỡ, nhóm cỡ nhỏ như cá bãi trầu, cá lành canh xiêm, cá lòng tong đuôi đỏ chiếm tỷ lệ nhiều, nhóm này sống được ở nhiều thủy vực khác nhau, không gian hẹp, nước cạn, đặc biệt ở các sinh cảnh bèo, lục bình, súng. Chúng ăn sinh vật phù du, nhóm này có vai trò rất quan trọng trong mạng lưới thức ăn là mắt xích quan trọng trong hệ sinh thái.

Sự đa dạng thành phần loài cá ở vùng lõi không có sự biến động lớn theo thời gian và không gian, do vùng lõi là rừng nguyên sinh dạng hỗn giao, tức là có nhiều loại cây cùng sinh sống chứ không rõ nét phân bố cho từng sinh cảnh riêng biệt, ví dụ: rừng tràm vẫn có súng, bèo lục bình và khu vực trảng vẫn có tràm, kênh mương vẫn có bèo và lục bình, tùy độ sâu mà cấu trúc thực vật này có sự thay đổi nhiều hay ít (Phạm Văn Tùng, 2017). Các quá trình sinh học diễn ra cục bộ trong phạm vi vùng lõi, ít bị tác động bởi các yếu tố bên ngoài ngoại trừ mức nước, thời điểm mức nước cao nhất vào khoảng tháng 10 - tháng 12 lúc này cá phát tán rộng lên rừng, trảng cao nên mật độ cá thưa hơn so với các tháng mùa cạn (tháng 3 và tháng 5 ).

Theo Sarma \& Das (2004) chỉ số Shannon H' dao động từ $1,5-3,5$, chỉ số này càng gần 3,5 thì đa dạng sinh học càng cao. Ở trảng bèo - lục bình và rừng tràm (Hình 6) chỉ số $\mathrm{H}^{\prime}$ thấp hơn, nơi đây tập trung chủ yếu là cá lớn (nhóm cá đen: cá lóc, cá rô đồng, cá trê trắng và cá trê vàng), trong khi vùng trảng súng, bèo, kênh tập trung nhiều loài cá lớn nhỏ khác nhau (nhóm cá bãi trầu, cá bống, cá lòng tong, cá thát lát, cá rô biển). Ở vùng đệm còn hiện diện cá nước lợ như cá rô phi vì mùa khô xung quanh vùng lõi bị nhiễm mặn (Phạm Văn Tùng, 2017), theo Seaby \& Henderson (2007), chỉ số Shannon H' biến động từ 1,6-2,5, chỉ số đa dạng Simpson (1-D: 0,8) cho thấy tính đa dạng nơi này ở mức cao và ổn định.

\section{KẾT LUẦN}

Nguồn lợi cá ở vùng lõi VQG UMT bị tác động bởi nhiều yếu tố, trong đó thiếu nước vào mùa khô là lý do dẫn đến cá chết cạn và bị săn bắt nhiều bởi các nhóm săn mồi khác trong mùa khô, điều tiết và quản lý nước là yếu tố có vai trò quyết định đến nguồn lợi thủy sản. Nghiên cứu này đã xác định được 32 loài cá thuộc 6 bộ và 17 họ, trong đó sự phân bố giữa các loài không rõ ràng giữa các sinh cảnh và các thời điểm khác nhau trong năm mà phụ thuộc vào mức nước có trong vùng lõi. Kết quả cũng cho thấy không thể tác động vào việc điều tiết nước để phục vụ nuôi trồng thủy sản tại VQG U Minh
Thượng vì mục đích chính ở nơi này là bảo vệ rừng tràm.

\section{LỜI CẢM TẠ}

Đề tài này được tài trợ bởi Dự án nghiên cứu giải pháp quản lý và bảo tồn đa dạng những loài cá có giá trị kinh tế tại Vườn Quốc gia U Minh Thượng, tỉnh Kiên Giang từ nguồn kinh phí của Sở Khoa học và Công nghệ tỉnh Kiên Giang.

\section{TÀI LIỆU THAM KHẢO}

Altieri, M. A. (2002). Agroecology: the science of natural resource management for poor farmers in marginal environments. Agriculture, Ecosystems \& Environment, 93(1-3), 1-24.

Bailey, K. L., \& Lazarovits, G. (2003). Suppressing soil-borne diseases with residue management and organic amendments. Soil and tillage research, 72(2), 169-180.

Bianchi, F. J., Booij, C. J. H., \& Tscharntke, T. (2006). Sustainable pest regulation in agricultural landscapes: a review on landscape composition, biodiversity and natural pest control.

Proceedings of the Royal Society B: Biological Sciences, 273(1595), 1715-1727.

Bibi, F., \& Ali, Z. (2013). Measurement of diversity indices of avian communities at Taunsa Barrage Wildlife Sanctuary, Pakistan. The Journal of Animal \& Plant Sciences, 23(2), 469-474.

Bộ Tài nguyên và Môi trường. (23/02/2016). Trao chưng nhận khu Ramsar cho VQG U Minh Thuoong. https://baotainguyenmoitruong.vn/botn-mt-trao-chung-nhan-khu-ramsar-cho-vqg-uminh-thuong-227572.html

Bùi Hữu Mạnh. (01/2012). Danh muc các loài cá nước ngọt Vườn Quốc gia U Minh Thuợng (2010-2011). Wildlife at Risk. https://wildlifeatrisk.org/wpcontent/ uploads/ 2019/01/ technical report.Ca_UMT_checklist_combined.pdf, 2 trang.

Đỗ Thị Như Uyên \& Hoàng Thị Nghiệp. (18/10/2013). Dẫn liệu bước đầu về thống kê, đánh giá đa dạng sinh học ở Vườn Quốc gia Tràm Chim, huyện Tam Nông, tỉnh Đồng Tháp. Hội nghị khoa học toàn quốc về sinh thái và tài nguyên sinh vật lần thứ $5,885-889$. http://www.iebr.ac.vn/database/HNTQ5/885.pdf

Daly, A. J., Baetens, J. M., \& De Baets, B. (2018). Ecological diversity: measuring the unmeasurable. Mathematics, 6(7), 119.

FAO. (2019). The State of the World's Biodiversity for Food and Agriculture, J. Bélanger \& D. Pilling (Eds.). FAO Commission on Genetic Resources for Food and Agriculture Assessments. Rome. 572 pp. http://www.fao.org/3/CA3129EN/CA3129EN.pdf 
Hossain, M., \& Alam, M. (2015). Threatened fishes of the world: Plotosus canius Hamilton, 1822 (Siluriformes: Plotosidae). Croatian Journal of Fisheries, 73(1), 35-36.

Lương Văn Thanh \& Phạm Văn Tùng. (2011). Biên hội, đánh giá tổng quan sinh thái Vuờn Quốc gia U Minh Thuợng và đề xuất giải pháp bảo tồn. Sở Khoa học và Công nghệ tỉnh Kiên Giang.

Lê Phát Quới \& Vũ Ngọc Long. (2012). Đất than bùn vùng $U$ Minh, đặc tính và hệ sinh thái tụ nhiên. Viện Môi trường và Tài nguyên, Viện Sinh thái Miền Nam.

Lê Tấn Lợi \& Lý Trung Nguyên. (2015). Nghiên cứu các mô hình canh tác có hiệu quả cho vùng đệm Vườn Quốc gia U Minh Hạ, huyện U Minh, tỉnh Cà Mau. Tạp chí Khoa học Trương Đại học Cần Tho, 40, 69-80.

Mai Viết Văn. (2019). Thành phần loài cá, tôm phân bố vùng dự án thủy lợi Ô Môn - Xà No. Tạp chí Khoa học Truò̀ng Đại học Cần Tho, 55(2), 51-60.

Nguyễn Xuân Đồng \& Kiên Thái Bích Nga. (2014). Ghi nhận bước đầu về thành phần loài cá thuộc bộ Cá vược ở hạ lưu sông Sài Gòn - Đồng Nai. Tạp chí Khoa học và Phát triển, 12(5), 665-674.

Nguyễn Hằng. (2016). Vườn Quốc gia U Minh Thượng trở thành khu Ramsar thứ 8 của Việt Nam. Tạp chí Môi truò̀ng, 2, 6.

Nguyễn Thị Ngọc Trân, Huỳnh Bảo Anh Quân, Nguyễn Thanh Lam, Trần Đắc Định \& Dương Thúy Yên. (2020). Thành phần loài cá trong vùng đệm khu bảo tồn $U$ Minh Thượng và $U$ Minh Hạ. Tạp chí Khoa học Truoòng Đại học Cần Tho, 56(1), 185-191

Okpiliya, F. I. (2012). Ecological diversity indices: Any hope for one again. Journal of Environment and Earth Science, 2(10), 45-52.

Phạm Văn Tùng (2017). Nghiên cúu, đề xuất chế độ nước hợp lý để phát triển rùng tràm sinh thái Vuờn Quốc gia U Minh Thuợng (Luận án tiến sĩ). Viện Khoa học Thủy lợi Miền Nam.

Rainboth, W. J. (1996). FAO species identification field guide for fishery purpose. Fish of the Cambodian Mekong, Rome, 265.

Safford, R. J., Trần Triết, Maltby, E., \& Dương Văn Ni. (1998). Status, biodiversity and management of the U Minh wetlands, Vietnam. Tropical Biodiversity, 5(3), 217-244.

Sarma, P., \& Das, D. (2004). Application of Shannon's index to study diversity with reference to census data of Assam. Asian Journal of Management Research, 5(4), 620-628.

Seaby, R. M. H., \& Henderson, P. A. (2007). SDRIV Help Measuring and Understanding Biodiversity. Pisces Conservation Ltd., Lymington, Hampshire.
Somerfield, P. J., Clarke, K. R., \& Warwick, R. M. (2008). Simpson index. Elsevier.Taylor, W. W., Welcomme, R. L., Bartley, D. M., Goddard, C. I., \& Leonard, N. J. (2016). Freshwater, fish and the future: proceedings of the global crosssectoral conference. Food and Agriculture Organization of the United Nations.

Trần Quang Bảo \& Phạm Văn Duẩn. (2011). Đặc điểm sinh trưởng và tăng trưởng của rừng tràm phục hồi sau cháy ở Vườn Quốc gia U Minh Thượng. Tạp chí Nông nghiệp và Phát triển Nông thôn, 24, 1-12.

Trần Đắc Định, Shibukawa K., Nguyễn Thanh Phương, Hà Phước Hùng, Trần Xuân Lợi, Mai Văn Hiếu \& Utsugi, K. (2013). Mô tả định loại cá Đồng bằng sông Củu Long, Việt Nam. Nhà xuất bản Đại học Cần Thơ.

Trần Văn Thắng. (2016). Điều tra, đánh giá và đề xuất giải pháp quản lý, khai thác bền vũng nguồn tài nguyên lâm sản ngoài gồ ở Vườn Quốc gia U Minh Thương. Đề tài khoa học cấp tỉnh của Sở Khoa học - Công nghệ và Vườn Quốc gia U Minh Thượng tỉnh Kiên Giang.

Tran, T., T. V., Phan, K. L. \& Durand, J. D. (2016). Diversity and distribution of cryptic species within the Mugil cephalus species complex in Vietnam. Mitochondrial DNA Part A, 28(4), 493-501. http://dx.doi.org/10.3109/24701394.2016.1143467

Trần Văn Việt, Nguyễn Trung Tín \& Lê Hồng Tuyến. (2020). Tình hình sinh kế của cộng đồng ở vùng đệm Vườn Quốc gia $\mathrm{U}$ Minh Thượng, tỉnh Kiên Giang. Tạp chí Khoa hoc Truò̀ng Đại hoc Cần Tho, 56(3), 143-152.

Trần Đắc Định, Nguyễn Thị Vàng, Nguyễn Trung Tín \& Dương Văn Ni. (2020). Khảo sát thành phần loài cá ở Vườn Quốc gia Tràm Chim, Đồng Tháp. Tạp chi Khoa học Công nghệ Nông nghiệp Việt Nam, 6(115), 137-142.

Thủ tướng Chính phủ. (2002). Quyết định về việc chuyển hạng khu bảo tồn thiên nhiên UMinh Thượng, tỉnh Kiên Giang thành Vườn Quốc gia (Số 11/2002/QĐ-TTg). https://thuvienphapluat.vn/vanban/Tai-nguyen-Moi-truong/Quyet-dinh-11-2002QD-TTg-chuyen-hang-khu-bao-ton-thien-nhien-UMInh-Thuong-tinh-Kien-Giang-thanh-vuon-quocgia-48879.aspx

Võ Tòng Anh. (2013). Báo cáo tăng cuoòng các biện pháp kiểm soát phòng cháy rùng cho các khu vưc đất than bùn U Minh Kiên Giang và Cà $M a u$. Dự án Phục hồi và Sử dụng bền vững đất than bùn ở khu vực Đông Nam Á (Peatland) Hợp phần Việt Nam. Thành phố Hồ Chí Minh.

Vũ Nguyễn Hoàng Giang \& Trần Bá Hoàng. (2016). Báo cáo Đánh giá tác động của việc nuôi Cá tra lên các khu đất ngập nước ở ĐBSCL. Viện Khoa học Thủy lợi Miền nam, Bộ Nông nghiệp và Phát triển Nông thôn. 